\title{
BioValley College Network (BCN): Trinational Network to Intensify the Teaching of Natural Science at Gymnasia Level
}

\author{
Janine Hermann*
}

\begin{abstract}
The BioValley College Network (BCN, www.biovalley-college.net) was created in autumn 2003, namely to improve the cross-linkage of the gymnasia/cantonal schools located in the regions South Baden, Alsace and Basel on the one hand, and with research and the economy in the field of Life Sciences in the BioValley (Regio Basiliensis) on the other. Therefore, BCN is an example of a Public Private Partnership. Today 13 high school teachers (2 from Germany, 3 from France and 8 from Switzerland) are active members of the BCN Board and more than 100 high school teachers are passive members of the network.
\end{abstract}

Keywords: BioValley · Life Sciences careers · Science outreach · Teacher enrichment · Trinational network

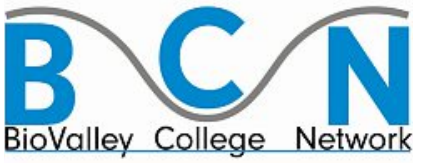

\section{Core Objectives of the BioValley College Network (BCN)}

- Furtherance of engaged and gifted young persons in the field of Life Sciences through the definition and implementation of a 'Curriculum Plus in Life Sciences'.

- Support for teaching staff imparting the knowledge of Life Sciences (Symposia, School Laboratories, School Congresses, Life Sciences Practicals in the Universities and the industries).

- Intensification and enrichment of the teaching of natural science at gymnasia level.

- Minimization of the loss of competence incurred on the critical career interfaces.

- Increase the number of students in Life Sciences studies such as medicine, biology, chemistry and so on.
*Correspondence: J Hermann

Head of Educationals, Interpharma.ch

BioValley College Network

Sekretariat BCN

Petersgraben 35

$\mathrm{CH}-4003$ Basel

Tel.: +41612643458

Fax: +4161264 3401

E-mail: janine.hermann@interpharma.ch

\section{Structures and Events}

There are currently five $\mathrm{BCN}$ school laboratories. They are located in the following high schools:

- Switzerland: Gymnasium Kirschgarten Basel, Gymnasium Muttenz

- Germany: Gymnasium Weil am Rhein, Gymnasium Bad Krozingen

- France: Lycée Mulhouse, Lycée Guebwiller

Every BCN teacher who is willing to enhance modern biology in her/his school receives the necessary equipment for PCR and so on from Interpharma. Teachers are paid for the lessons they teach in the BCN labs. They not only teach classes from their own school but also invite classes from outside who are interested. The chemicals required are mainly sponsored and delivered by Schullabor Novartis. During these lessons, the high school students learn modern biochemical and molecular biological tools and achieve hands-on practices such as:

- Transformation of E. coli bacteria with resistance plasmid;

- Plasmid extraction from E. coli bacteria;

- Restriction of isolated plasmid DNA with restriction endonucleases;

- Gel electrophoreses of DNA;

- DNA extractions from diverse organisms;

- Influence of UV radiation on plasmids, bacteria and yeast cells.

In 2011 around 700 students visited the BCN school laboratories with their teachers.

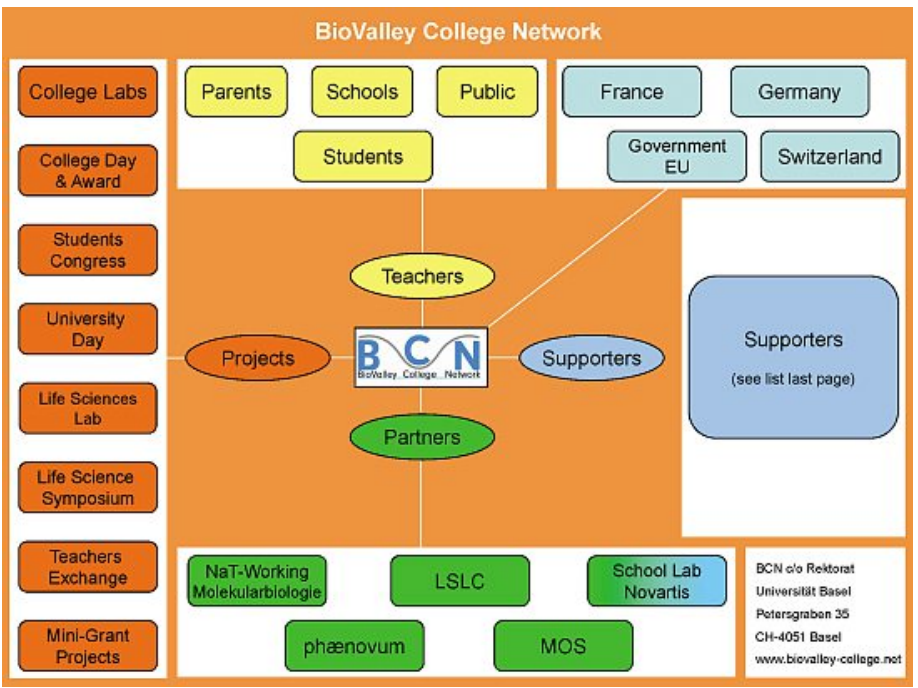

Partners of the BCN. 


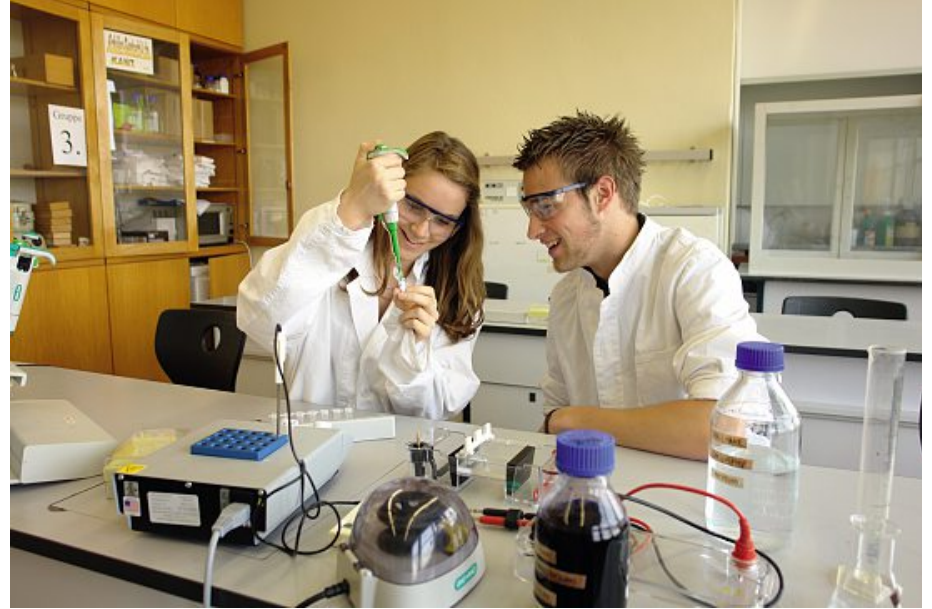

Two students performing an experiment in a BCN lab.

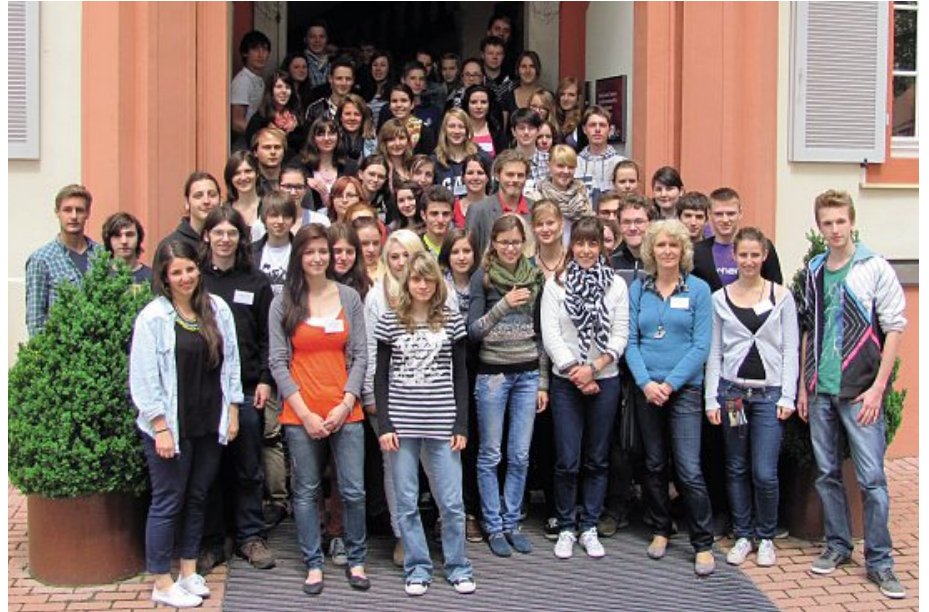

Students at Schloss Beuggen DE.

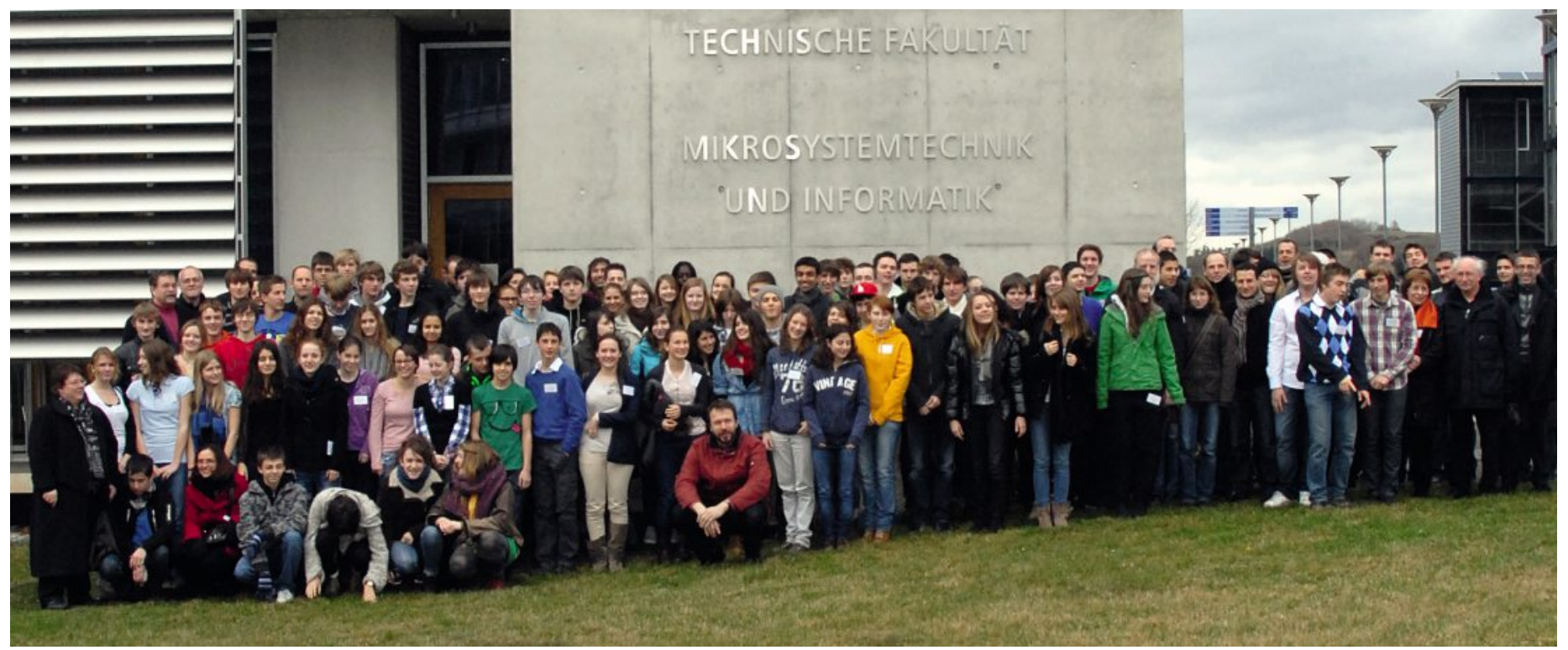

Students at University of Freiburg im Breisgau DE.

\section{Trinational Scholar Congresses}

Every year the BCN organizes two Scholar Congresses. This year the congress 'Natural Sciences and Technique' was held in Le Vaisseau in Strasbourg FR and the 'Life Science Congress' took place in Schloss Beuggen DE. Around 100 students with their teachers had the possibility to present their science projects to a trinational audience and come into contact with researchers from all around the world and meet with people from the industry. Workshops are held and possible careers are discussed.

\section{BioValley College Day}

Every year in October the BioValley College Day takes place in Basel. Around 450 students from the three countries gather in the aula of the University of Basel to listen to keynote speakers from all over the world. Actual research results are discussed and a selected number of students present their diploma work. The College Day Award of 3,000 CHF is awarded to the best student presentations. They also get the chance to familiarize themselves with Life Sciences studies and meet students from different sections of the University and the School for Higher Education (Fachhochschule).

\section{Life Sciences Symposium for Teachers}

On the $24^{\text {th }}$ of March 2012 the $5^{\text {th }}$ Life Science Symposium for high school teachers was held at the Kantonsschule Wettingen. More than 140 teachers from 


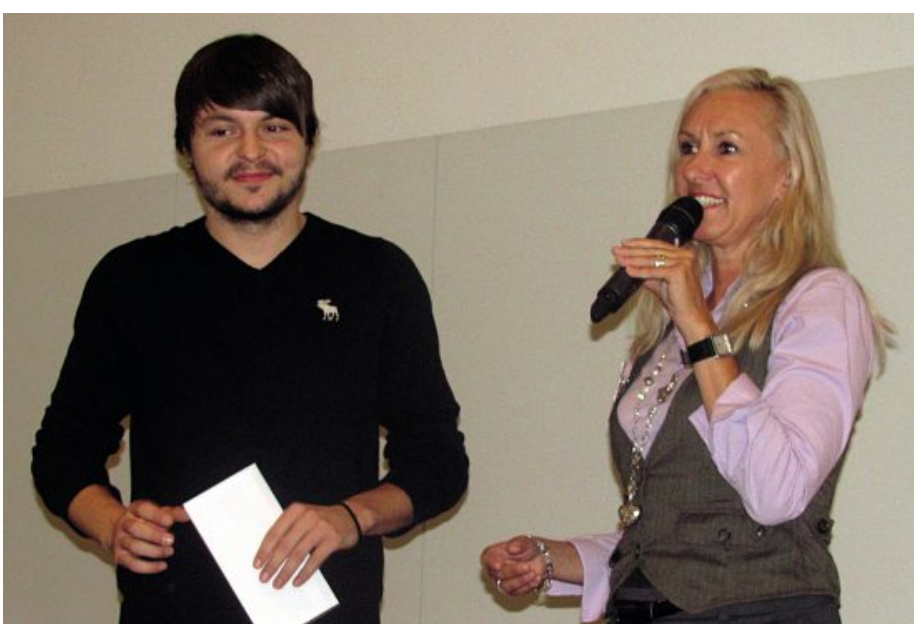

The student who won the College Day Award in 2011.
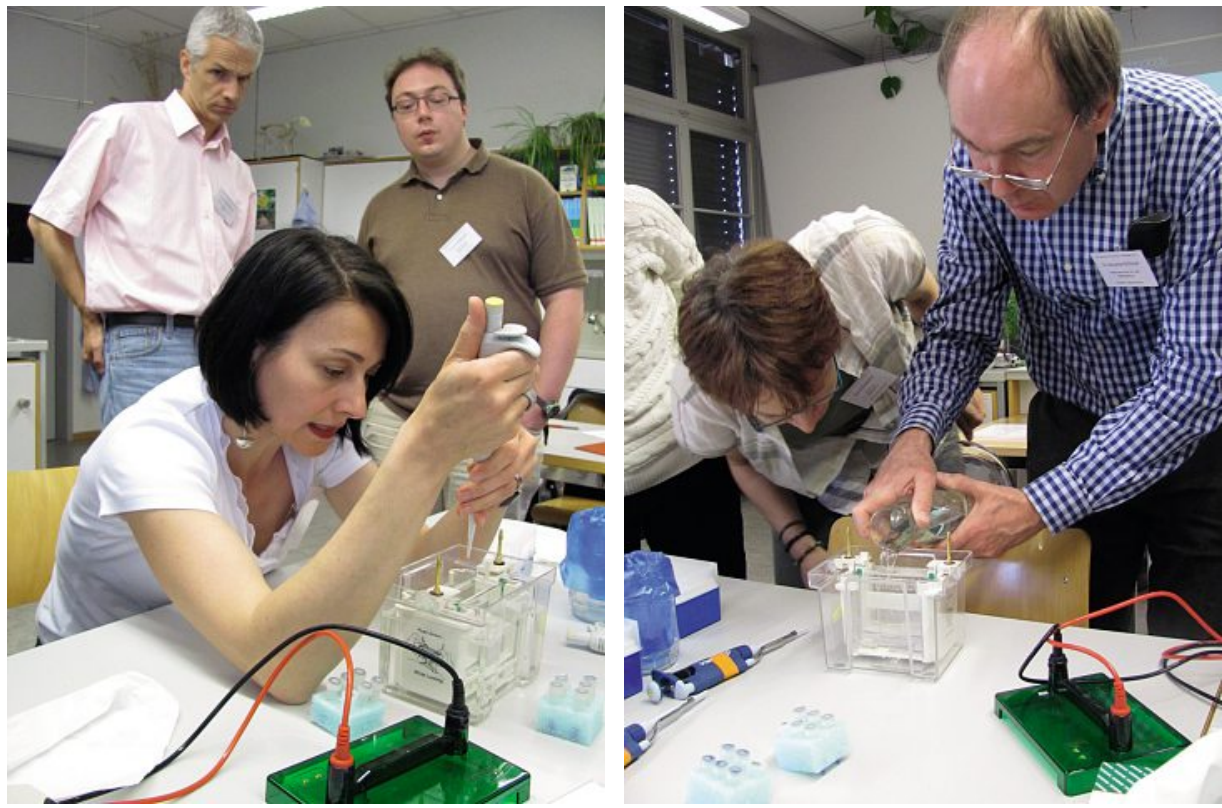

High school teachers taking part in a workshop.

three nations gathered to listen to top researchers and could choose two workshops according to their needs. A rich diversity of topics was offered and there was even a workshop leader from Boston who gave a workshop about modern Biotech teaching in Massachusetts's high schools. ects with teachers from $\mathrm{CH}, \mathrm{DE}, \mathrm{FR}$ and the USA (Mini-Grant Projects, as well as the Biotech Symposium) have resulted in an intensive exchange of ideas between the $\mathrm{BCN}$ and high schools in the region of Boston and were co-ordinated by the Museum of Science, MOS Boston. In 2011 three high school teachers had the opportunity to travel to Woods Hole (near Boston) to take part in the international Wolbachia project. This sabbatical was financed by Actelion Pharmaceuticals and was a great success because the knowledge that these teachers gained during their stay is now transmitted to their BCN colleagues and their classes, and important data is collected in the classes of the three nations that contribute to the international Wolbachia project.

\section{Partners of the $\mathrm{BCN}$}

Main Supporters of the BCN:

- Education Departments of the Cantons Basel-Stadt, Basel-Land ( $\mathrm{CH})$ and Aargau (CH)

- Regierungspräsidium Freiburg im Breisgau, Department Schools \& Education (DE)

- Académie de Strasbourg, Pole Pédagogique (FR)

- Interpharma, association of researchbased Swiss pharmaceutical companies, Basel $(\mathrm{CH})$

\section{Conclusion}

There is a very firm opinion in the BioValley that the competitiveness and prosperity of the region on the Rhine Bend depend greatly on an excellent education and further training in the core disciplines of life sciences and biomedicine.

Received: September 24, 2012 